medRxiv preprint doi: https://doi.org/10.1101/2020.04.08.20057943; this version posted April 20, 2020. The copyright holder for this preprint (which was not certified by peer review) is the author/funder, who has granted medRxiv a license to display the preprint in perpetuity. It is made available under a CC-BY-NC-ND 4.0 International license .

\title{
Estimating the Growth Rate and Doubling Time for Short-Term Prediction and Monitoring Trend During the COVID-19 Pandemic with a SAS Macro
}

\author{
Stanley $\mathrm{Xu}^{1,2}$, Christina Clarke ${ }^{1}$, Susan Shetterly ${ }^{1}$, Komal Narwaney ${ }^{1}$ \\ ${ }^{1}$ The Institute for Health Research, Kaiser Permanente Colorado, 2550 S. Parker Road, \\ Aurora, CO 80014 \\ ${ }^{2}$ School of Public Health, University of Colorado, 13001 E 17th PI, Aurora, CO 80045
}

\begin{abstract}
Coronavirus disease (COVID-19) has spread around the world causing tremendous stress to the US health care system. Knowing the trend of the COVID-19 pandemic is critical for the federal and local governments and health care system to prepare plans. Our aim was to develop an approach and create a SAS macro to estimate the growth rate and doubling time in days if growth rate is positive or half time in days if growth rate is negative. We fit a series of growth curves using a rolling approach. This approach was applied to the hospitalization data of Colorado State during March $13^{\text {th }}$ and April $13^{\text {th }}$. The growth rate was $0.18(95 \% \mathrm{Cl}=(0.11,0.24))$ and the doubling time was 5 days $(95 \% \mathrm{Cl}=(4,7))$ for the period of March $13^{\text {th }}-$ March $19^{\text {th }}$; the growth rate reached to the minimum $-0.19(95 \% \mathrm{Cl}=(-0.29,-0.10))$ and the half time was 4 days $(95 \% \mathrm{Cl}=(2,6))$ for the period of April $2^{\text {nd }}-$ April $8^{\text {th }}$. This approach can be used for regional short-term prediction and monitoring the regional trend of the COVID19 pandemic.
\end{abstract}

\section{BACKGROUND}

In December 2019, an outbreak of coronavirus disease (COVID-19) caused by the novel coronavirus (SARS-CoV-2) began in Wuhan, China and has now spread across the world [1,2]. In the United States, the cumulative number of identified COVID-19 cases was 186,101 as of March 31st, 2020; among the identified cases, 3603 died [3]. To slow the spread of COVID-19, federal and local governments have issued mitigation measures such as case isolation, quarantine, school closures and closing non-essential businesses. The COVID-19 pandemic imposes tremendous challenges to the US health care system, particularly given concerns that the need for hospital beds and ICU beds could exceed capacity [4-6]. Predicting the future numbers of COVID-19 cases and healthcare utilization is critical for governments and health care systems preparation plans $[4,6,7]$. Two useful and critical quantities for prediction are the growth rate [8] and the doubling time of number of events [9]. The growth rate is the percent change of daily events (e.g, COVID-19 cases, number of patients hospitalized or number of deaths). The doubling time is the length of time required to double the number of daily events.

Our goal was to develop an approach and create a SAS macro using observed data to estimate the growth rate and doubling time in days for short-term prediction. 
medRxiv preprint doi: https://doi.org/10.1101/2020.04.08.20057943; this version posted April 20, 2020. The copyright holder for this preprint (which was not certified by peer review) is the author/funder, who has granted medRxiv a license to display the preprint in perpetuity. It is made available under a CC-BY-NC-ND 4.0 International license .

\section{METHODS}

\subsection{A rolling growth curve approach (RGCA)}

In the United States, there are several barriers for testing people for COVID-19 such as shortages of swabs and testing kits and restrictions on who should get tested.

Therefore, the number of COVID-19 cases is often under-identified and under-reported. However, the number of hospitalized COVID-19 patients (hospitalizations) and number of deaths due to COVID-19 are more reliable than the reported number of COVID-19 cases [10]. In this paper, we used the number of daily hospitalized COVID-19 patients to calculate the growth rate and doubling time in days.

We assumed a growth curve of daily hospitalizations over a period of $n$ days from day $t$ (start day) to day $(t+n-1)$. Let $y_{(t+j-1)}$ denote the daily hospitalizations at day $(t+j-1), 1 \leq j \leq n$. Based on the growth model, we have

$$
y_{(t+j-1)}=y_{t}(1+r)^{j-1}
$$

where $y_{t}$ is the number of hospitalizations at the start day $t ; r$ is the growth rate. When the growth rate $r>0$, the number of daily hospitalizations increases. For example, if $r$ $=0.4$, the growth rate of hospitalizations is $40 \%$ more for each day. When growth rate $r=0$, the number of daily hospitalizations has no change. When growth rate $r<0$, the number of daily hospitalizations declines. When the number of hospitalizations doubles at $j=D$, that is $y_{(t+D-1)}=2 y_{t}$, we have,

$$
2 y_{t}=y_{t}(1+r)^{D-1}
$$

Further, it can be shown that

$$
r=e^{\left(\frac{\ln (2)}{D-1}\right)}-1
$$

We fit two models: a) using equation (1) which estimates the growth rate $r$; b) using equation (1) with $r$ substituted with $e^{\left(\frac{\ln (2)}{D-1}\right)}-1$ from equation (2). The second model estimates the doubling time in days $D$, meaning that it takes $D$ days from the start day $t$ for the number of daily hospitalizations to double. We used SAS PROC NLIN [11] to fit these two nonlinear models. Note that equation (2) is valid for $r>0$. When $r<0$, one can use $r=e^{\left(\frac{\ln (0.5)}{D-1}\right)}-1$; the estimated $D$ represents the days required to reduce the number of hospitalizations by half (half time).

Because the growth rate and doubling time may change over time, we used a rolling growth curve approach (RGCA). For example, we set the length of the period to be 7 days ( $\mathrm{n}=7$ days). We estimated the growth rate and the doubling time in days for the following periods for hospitalization data from Colorado State from March 13th - April 13th [12]: March $13^{\text {th }}-19^{\text {th }}, 14^{\text {th }}-20^{\text {th }}, 15^{\text {th }}-21^{\text {st }}, \ldots$, April $7^{\text {th }}-$ April $13^{\text {th }}$. 
medRxiv preprint doi: https://doi.org/10.1101/2020.04.08.20057943; this version posted April 20, 2020. The copyright holder for this preprint (which was not certified by peer review) is the author/funder, who has granted medRxiv a license to display the preprint in perpetuity. It is made available under a CC-BY-NC-ND 4.0 International license.

\subsection{Short-term prediction}

The estimated growth rate from the last period of the RGCA approach (e.g., April $7^{\text {th }}$ April $13^{\text {th }}$ ) can be used for future short-term prediction of hospitalizations. Let $k$ denote the last day of the last period, $y_{k}$ is the number of hospitalizations on this day. For the Colorado hospitalization data in this analysis, $k$ is April $13^{\text {th }}, y_{k}=36$. Let $m$ denote the date after date $k$, then the predicted $y_{m}$ is

$$
\bar{y}_{m}=y_{k}\left(1+\hat{r}_{k}\right)^{m-k}
$$

where $\hat{r}_{k}$ is the estimated growth rate from the last period. As the growth rate changes over time, the prediction is only appropriate for short-term prediction (e.g., within 7 days) and updated growth rates should be used.

\section{RESULTS}

We estimated a series of growth rates using RGCA with a length of 7 days. The estimated growth rates and $95 \%$ Cls were plotted over time using the mid-day of a 7 day period (Figure 1). The growth rate peaked with a value of $56.2 \%$ at the mid-day of March $18^{\text {th }}$ for the period March $15^{\text {th }}$ and March $21^{\text {st }}$. Between March $18^{\text {th }}$ and April $1^{\text {st }}$, although the growth rate continuously decreased, the daily number of hospitalizations increased because of positive growth rates. We started to observe negative growth rates after April $1^{\text {st }}$, except for a positive growth rate on April $9^{\text {th }}$. The growth rate reached its minimum at the mid-day of April $5^{\text {th }}$ (period April $2^{\text {nd }}-A$ April $8^{\text {th }}$ ) with a value of $-19.2 \%$. The growth rate then increased after April $5^{\text {th }}$. Note that a negative growth rate represents a reduction in number of hospitalizations.

The doubling time (growth rate $>0$ ) and half time (growth rate $<0$ ) in days over time are displayed in Figure 2 . Before April $1^{\text {st }}$, the $y$-axis represents the doubling time in days because of positive growth rates. After April $1^{\text {st }}$, except for a positive growth rate on April $9^{\text {th }}$, the $y$-axis represents a half-time because of negative growth rates. On April $1^{\text {st }}$, the reduction rate was very small $(0.5 \%)$ which resulted in a high half-time, 128 days with very wide $95 \% \mathrm{Cls}$ (not shown in the figure). On April $8^{\text {th }}$, there was a small reduction rate $(1.2 \%)$ resulting in 55 days of half time.

Using the estimated growth rate from the last period April $7^{\text {th }}$-April $13^{\text {th }}, \hat{r}_{k}=0.027$, the predicted numbers of daily hospitalizations for April $14^{\text {th }}$ and $15^{\text {th }}$ were 35 and 34 , respectively. SAS programs are available for conducting these analyses (Appendix A and Appendix B). 
medRxiv preprint doi: https://doi.org/10.1101/2020.04.08.20057943; this version posted April 20, 2020. The copyright holder for this preprint (which was not certified by peer review) is the author/funder, who has granted medRxiv a license to display the preprint in perpetuity. It is made available under a CC-BY-NC-ND 4.0 International license .

\section{DISCUSSION}

These models can be similarly applied to death data if they are available and not sparse. When COVID-19 testing is widely available to the public and the number of COVID-19 testing is less selective, these models can also be used to directly estimate the growth rate and the doubling time for COVID-19 cases. Due to a lag in reporting hospitalization, it is recommended to exclude the recent 1-2 days' hospitalization data in fitting the growth curves. This paper illustrates that hospitalization data can be used to estimate the growth rate and doubling (or half) time to aid predicting future hospitalizations, deaths and COVID-19 cases. Because a series of growth curves were fit, the RGCA approach can also be used for real-time monitoring of the epidemic trend as shown in Figure 1.

Colorado state issued three social distancing guidelines: a voluntary social distancing on March $17^{\text {th }}$, closing educational facilities on March $23^{\text {rd }}$, and closing non-essential services on March $26^{\text {th }}$ (Figure 1). It takes some time (e.g., 2 weeks) for these mitigation measures to have impact. Although the effectiveness of these mitigation measures has not been investigated formally, it is believed that they helped to slow the spread of COVID-19 and reduced number of hospitalizations and death in Colorado and across the United States.

\section{Acknowledgements}

This research was supported by the Institute for Health Research, Kaiser Permanente Colorado. Xu was also supported by NIH/NCRR Colorado CTSI Grant Number UL1 RR025780.

\section{REFERENCES}

1. CDC. 2019 Novel Coronavirus, Wuhan, China. Available at https://www.cdc.gov/coronavirus/2019-ncov/

2. WHO. WHO Director-General's opening remarks at the media briefing on COVID-19-11 March 2020

3. CDC. https://www.cdc.gov/coronavirus/2019-ncov/cases-updates/cases-inus.html

4. IHME COVID-19 health service utilization forecasting team. Forecasting COVID19 impact on hospital bed-days, ICU-days, ventilator days and deaths by US state in the next 4 months. MedRxiv. 26 March 2020. doi:10.1101/2020.03.27.20043752.

5. Ferguson NM, Laydon D, Nedjati-Gilani G, et al. Impact of non-pharmaceutical interventions (NPIs) to reduce COVID-19 mortality and healthcare demand. Imp Coll COVID-19 Response Team. March 2020:20. doi:https://doi.org/10.25561/77482

6. Tsai TC, Jacobson B, Jha AK. American hospital capacity and projected need for COVID-19 patient care. Health Aff (Millwood). March 2020. doi:10.1377/hblog20200317.457910 
medRxiv preprint doi: https://doi.org/10.1101/2020.04.08.20057943; this version posted April 20, 2020. The copyright holder for this preprint (which was not certified by peer review) is the author/funder, who has granted medRxiv a license to display the preprint in perpetuity. It is made available under a CC-BY-NC-ND 4.0 International license.

7. Petropoulos F, Makridakis S (2020) Forecasting the novel coronavirus COVID19. PLoS ONE 15(3): e0231236. https://doi.org/10.1371/journal.pone.0231236

8. Du Z, Xu X, Wu Y, Wang L, Cowling BJ, Ancel Meyers L. Serial interval of COVID-19 among publicly reported confirmed cases. Emerg Infect Dis. 2020 Jun [date cited]. https://doi.org/10.3201/eid2606.200357

9. Nunes-Vaz, R., 2020. Visualising the doubling time of COVID-19 allows comparison of the success of containment measures. Global Biosecurity, 1(3), p.None. DOI: http://doi.org/10.31646/gbio.61

10. https://covid19.healthdata.org/projections

11. SAS Institute, version 9.4, Cary, NC

12. https://covid19.colorado.gov/case-data (accessed on April 14th 2020) 
medRxiv preprint doi: https://doi.org/10.1101/2020.04.08.20057943; this version posted April 20, 2020. The copyright holder for this preprint (which was not certified by peer review) is the author/funder, who has granted medRxiv a license to display the preprint in perpetuity.

Figure 1. Estimated growth rate with $95 \%$ Cls over time using hospitalization data from Colorado State.

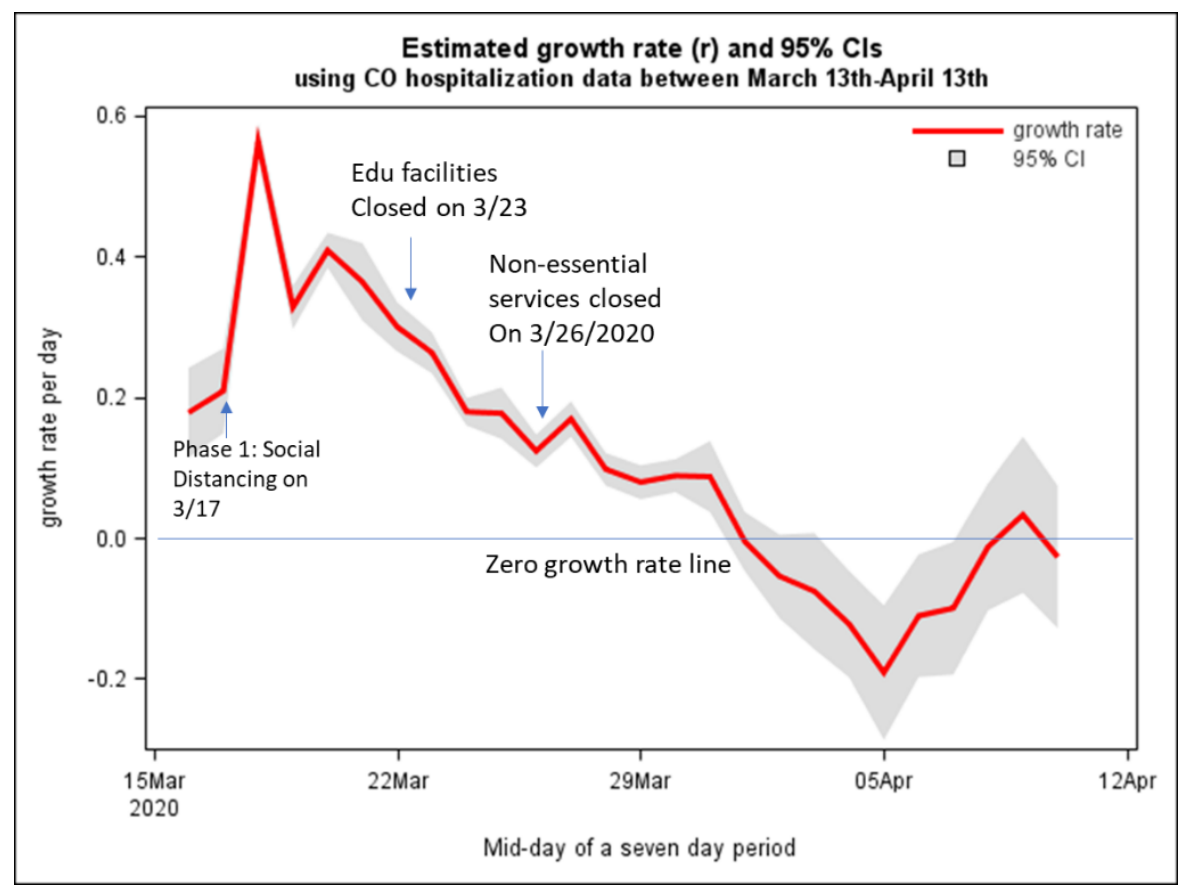

Figure 2. Estimated doubling (or half) time in days with 95\% Cls over time using hospitalization data from Colorado State.

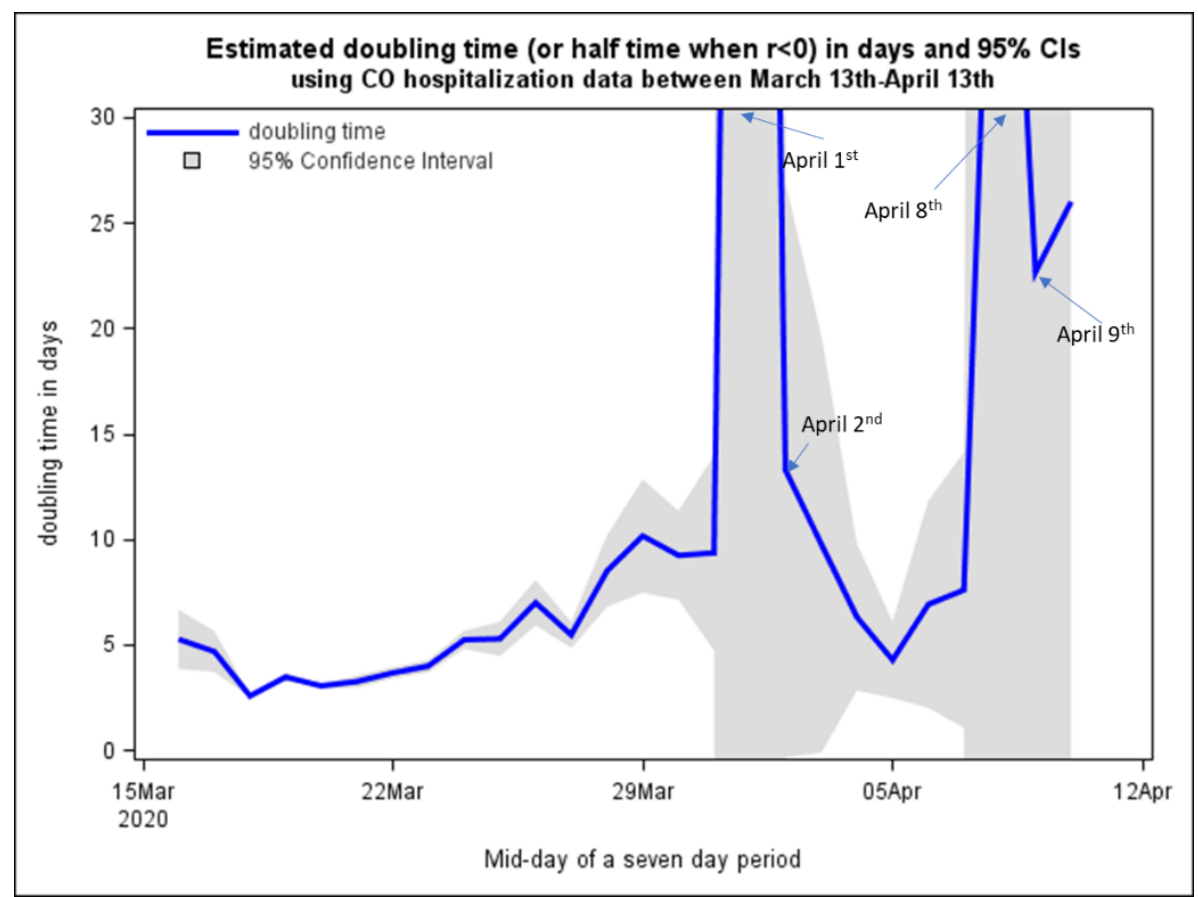


medRxiv preprint doi: https://doi.org/10.1101/2020.04.08.20057943; this version posted April 20, 2020. The copyright holder for this preprint (which was not certified by peer review) is the author/funder, who has granted medRxiv a license to display the preprint in perpetuity.

It is made available under a CC-BY-NC-ND 4.0 International license.

\section{APPENDIX A}

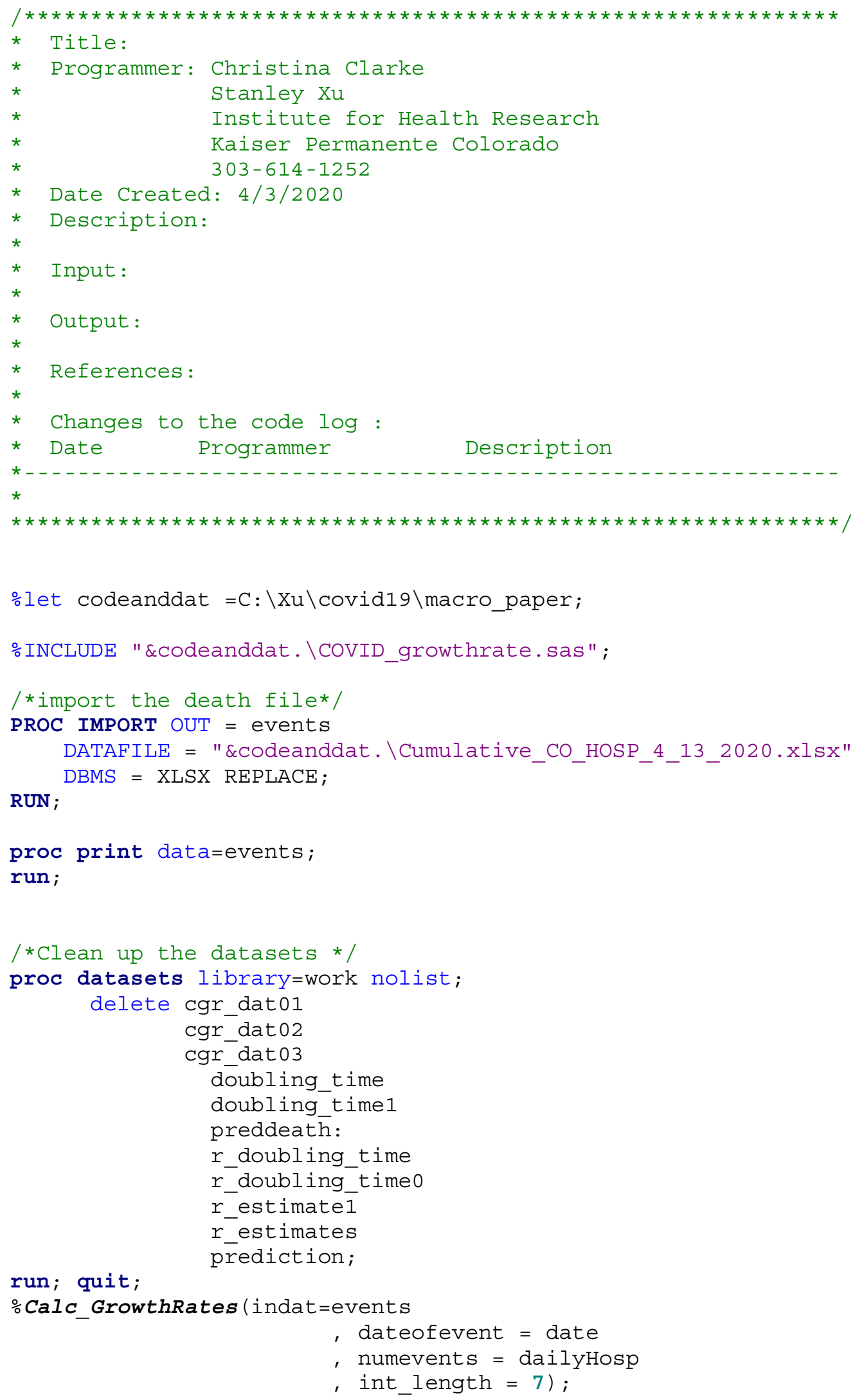




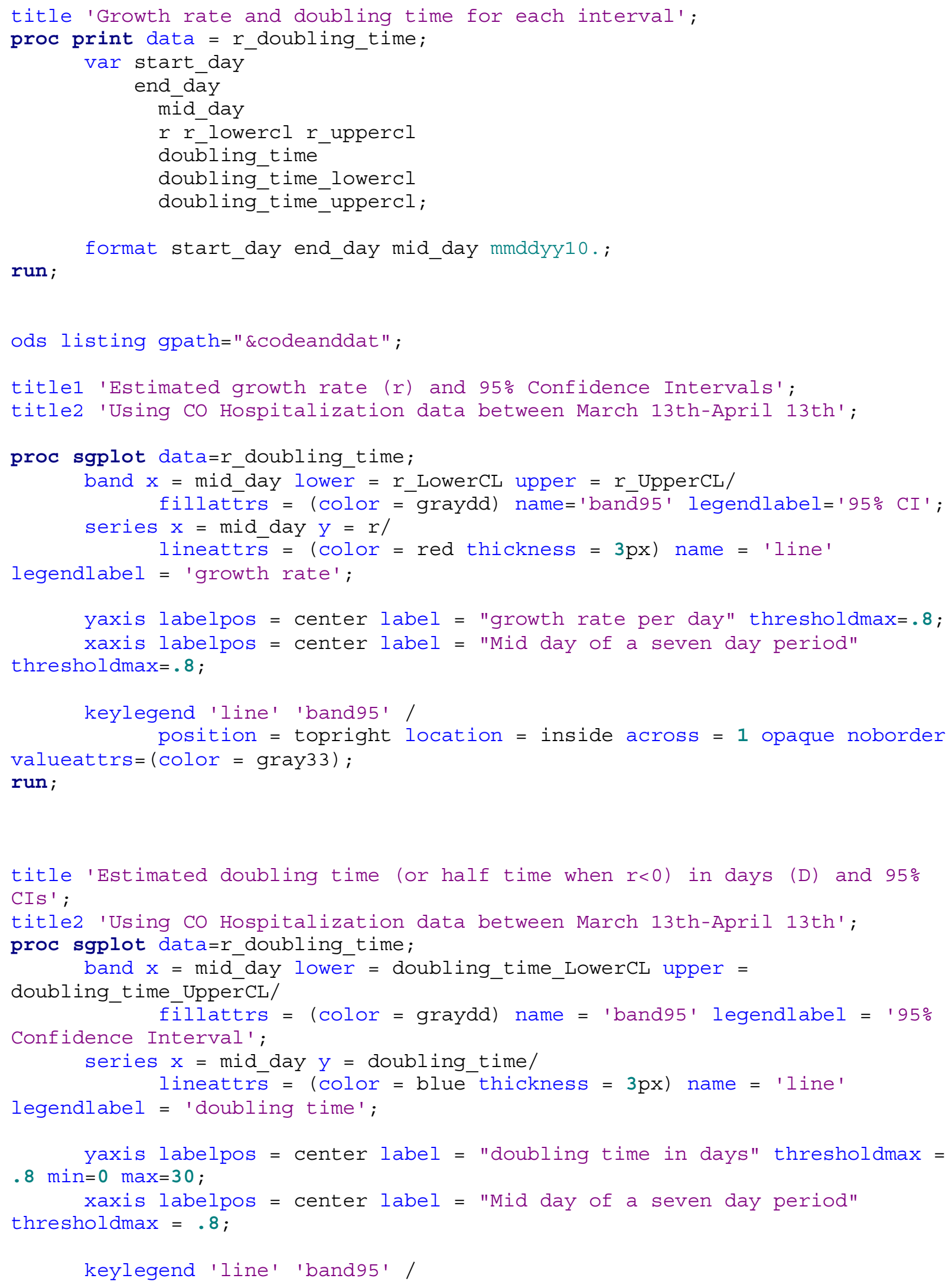


medRxiv preprint doi: https://doi.org/10.1101/2020.04.08.20057943; this version posted April 20, 2020. The copyright holder for this preprint (which was not certified by peer review) is the author/funder, who has granted medRxiv a license to display the preprint in perpetuity.

It is made available under a CC-BY-NC-ND 4.0 International license .

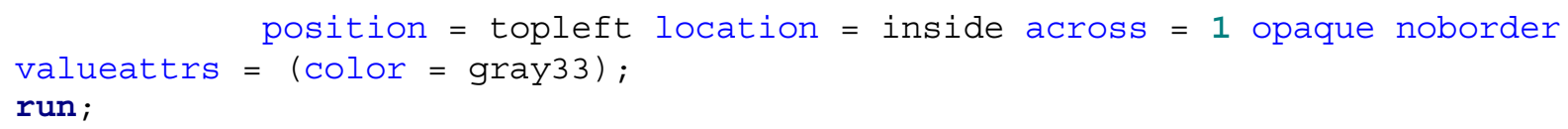

\section{APPENDIX B}

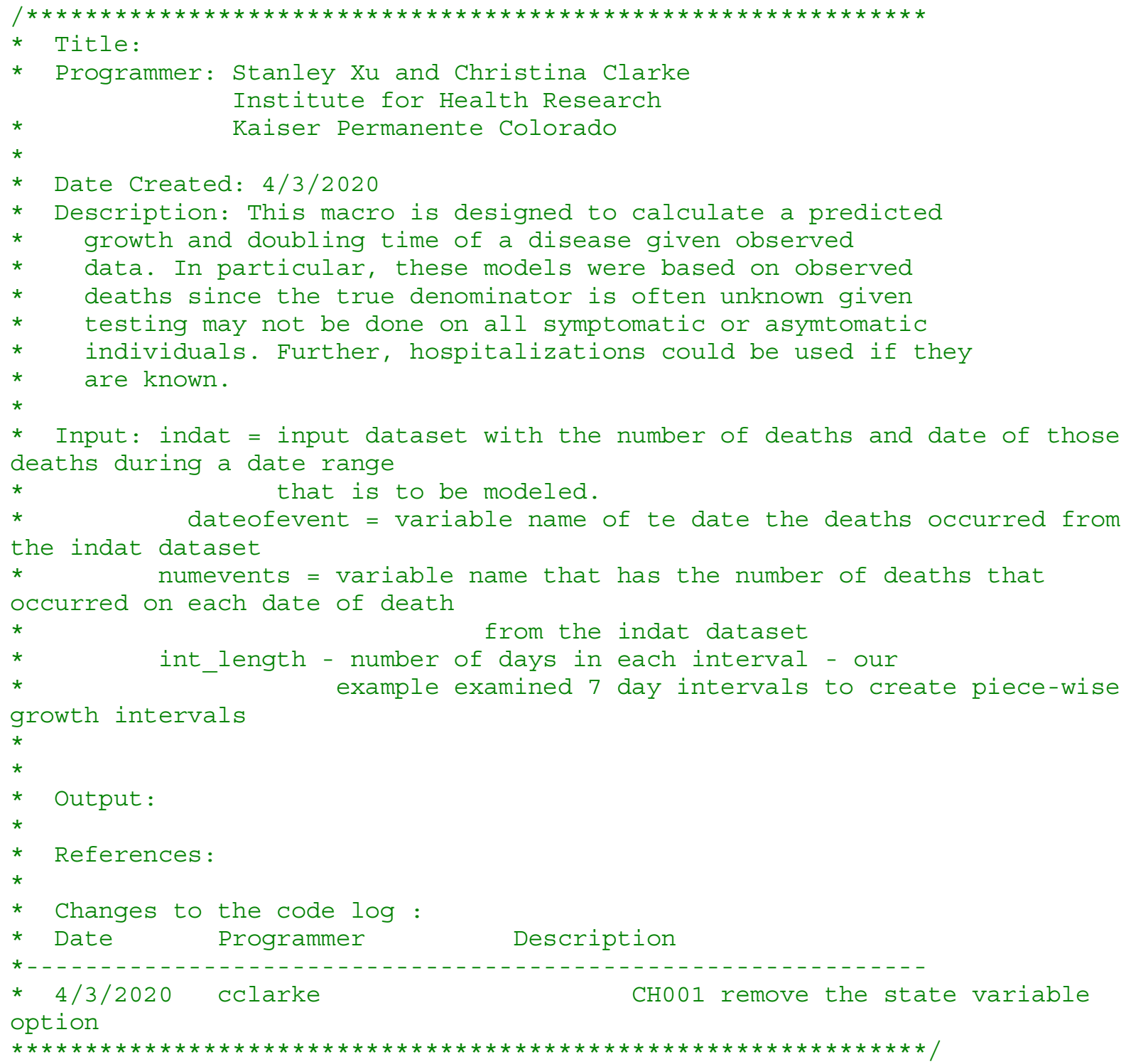

omacro Calc_GrowthRates (indat, dateofevent, numevents, int_length); *First, we need to get the start and end dates from the input dataset.; proc sql noprint; select distinct min(\&dateofevent) , max (\&dateofevent) 
medRxiv preprint doi: https://doi.org/10.1101/2020.04.08.20057943; this version posted April 20, 2020. The copyright holder for this preprint (which was not certified by peer review) is the author/funder, who has granted medRxiv a license to display the preprint in perpetuity. It is made available under a CC-BY-NC-ND 4.0 International license .

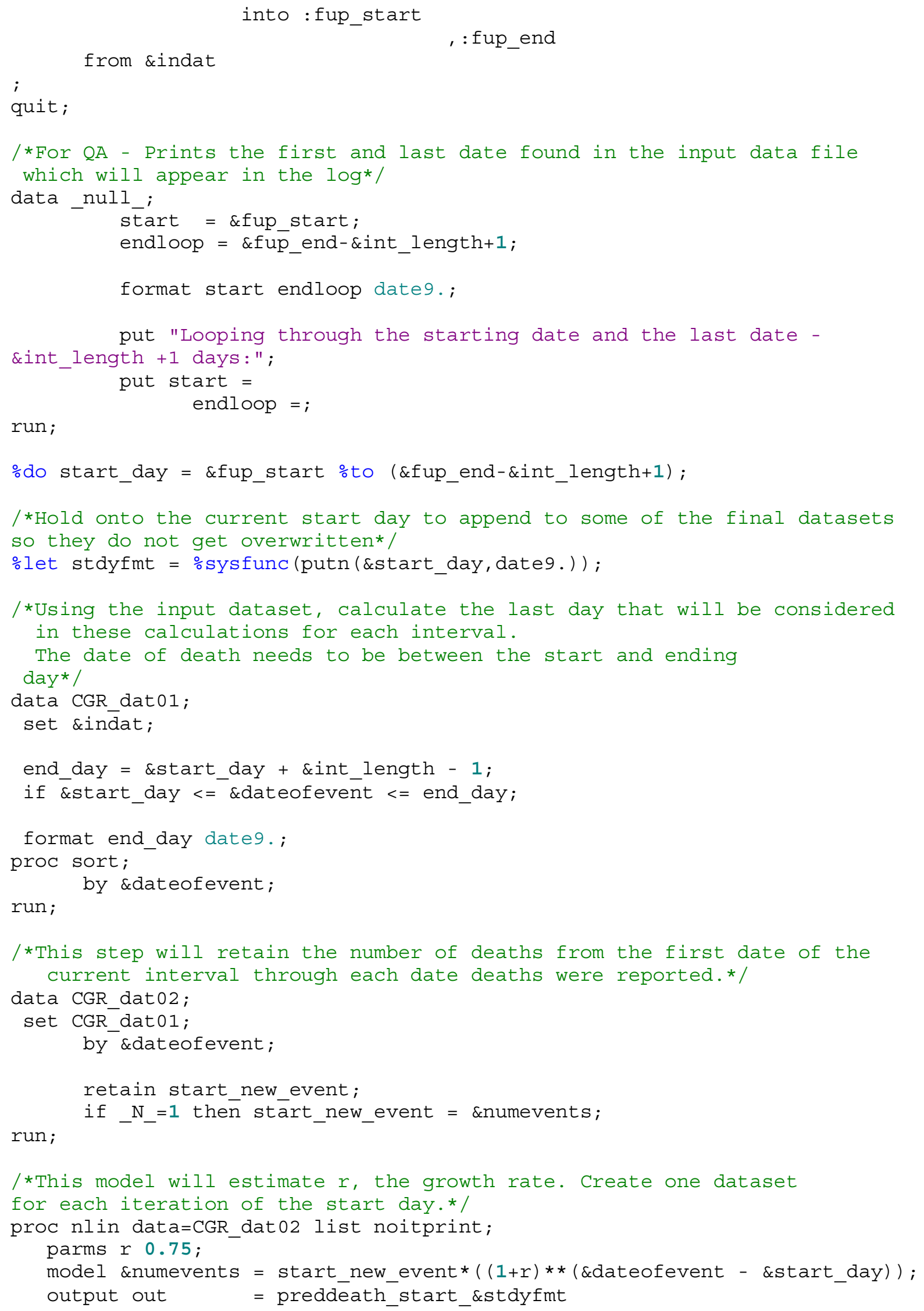




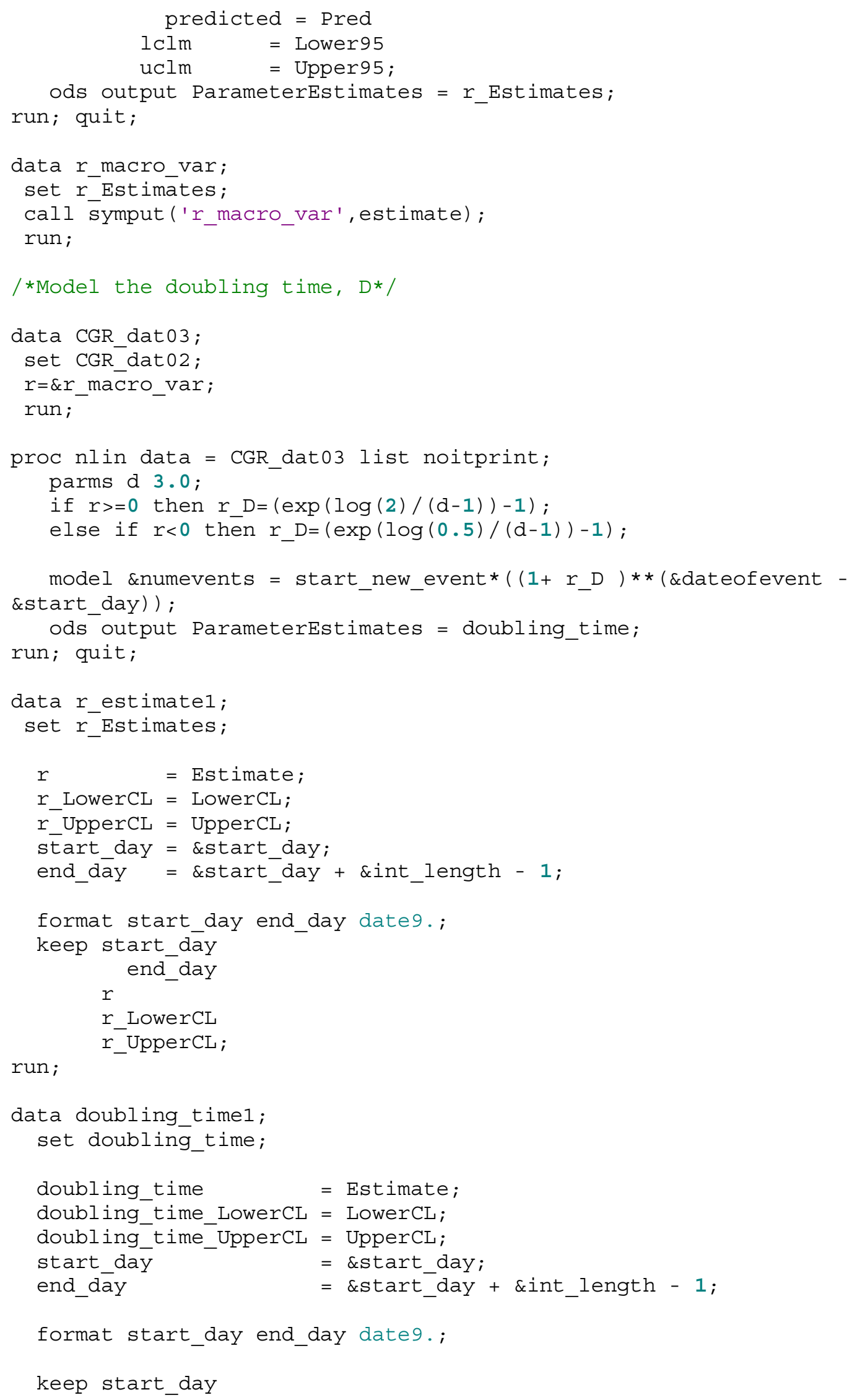




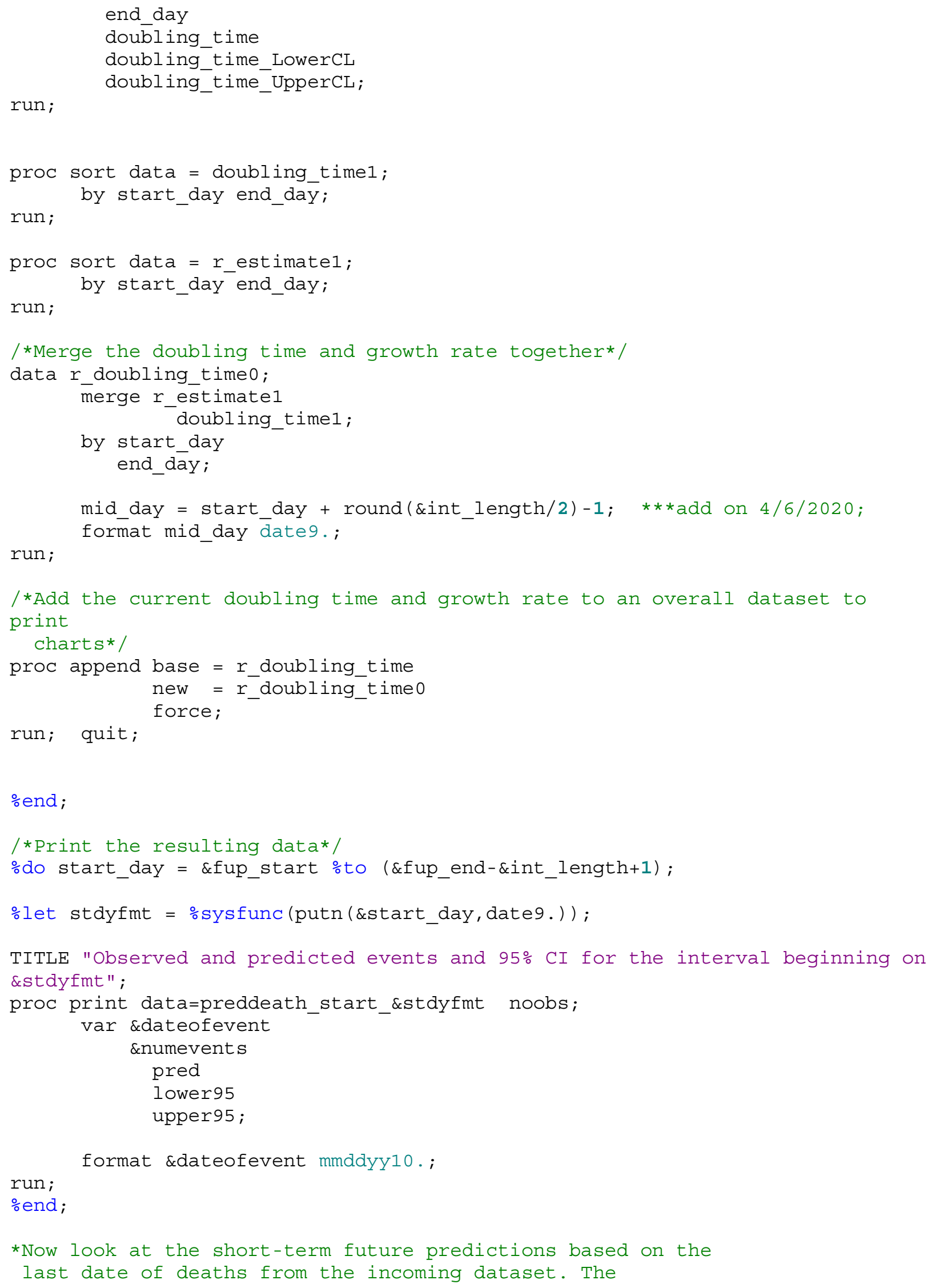


medRxiv preprint doi: https://doi.org/10.1101/2020.04.08.20057943; this version posted April 20, 2020. The copyright holder for this preprint (which was not certified by peer review) is the author/funder, who has granted medRxiv a license to display the preprint in perpetuity.

It is made available under a CC-BY-NC-ND 4.0 International license.

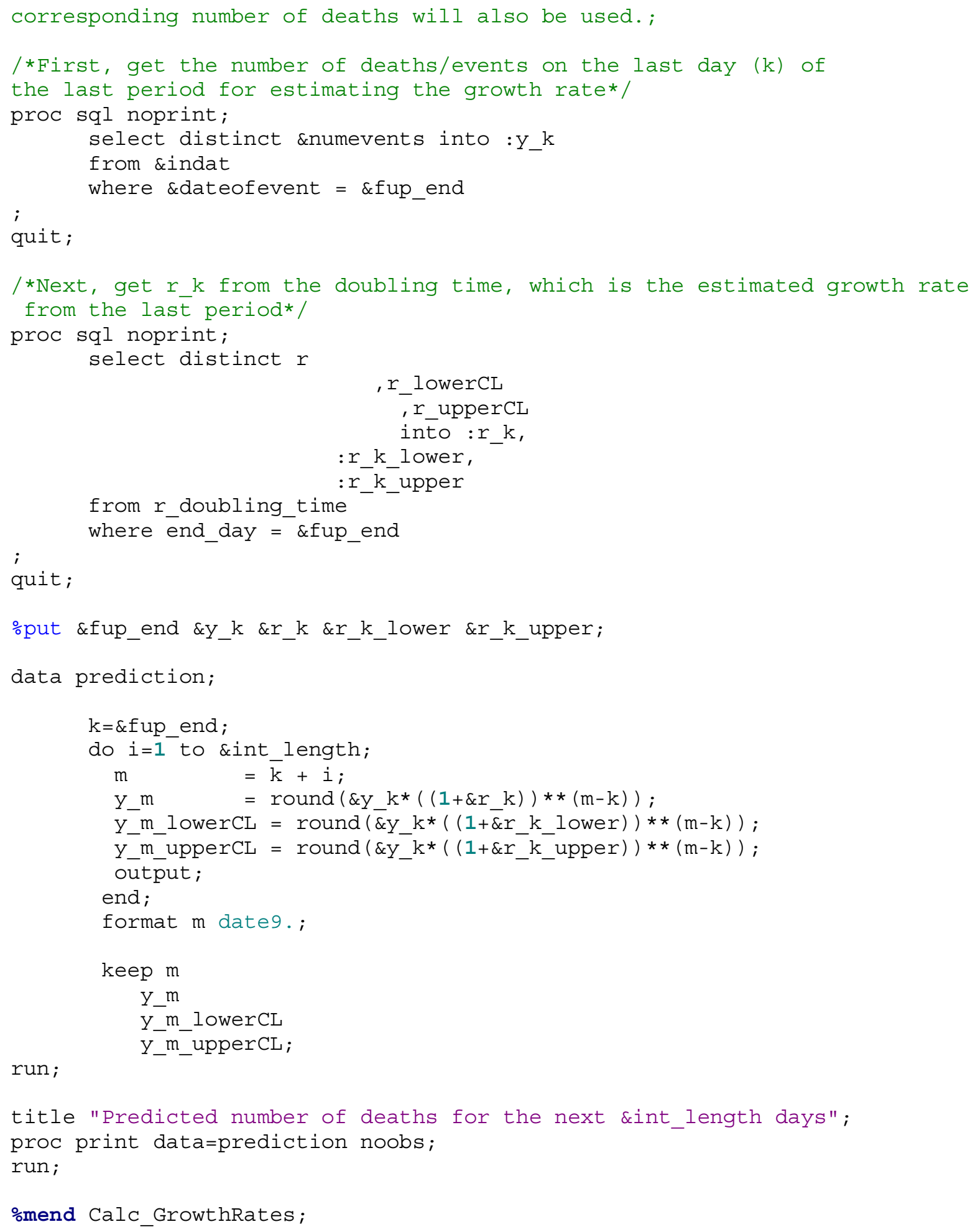

